\title{
THE ASSESSMENT OF ATMOSPHERIC DROUGHT DURING VEGETATION SEASON (ACCORDING TO STANDARDIZED PRECIPITATION INDEX SPI) IN CENTRAL-EASTERN POLAND
}

\author{
Elżbieta Radzka ${ }^{1}$ \\ 1 Department of Agrometeorology and Land Reclamation, University of Natural Sciences and Humanities, B. \\ Prusa 14, 08-110 Siedlce, Poland, e-mail: elzbieta.radzka@uph.edu.pl
}

Received: 2014.07.20

Accepted: 2014.10.17 Published: 2015.01.02

\begin{abstract}
The paper presents an assessment of atmospheric drought during vegetation season defined on the basis of standardized precipitation index (SPI). The data used in this paper come from nine IMWM stations from central-eastern region of Poland, and they were registered in 1971-2005. The frequency of occurrence of vegetation season's months was determined in particular drought classes. Spatial distribution of SPI index values was shown in all of the vegetation season's months on the area examined. The direction and significance of values changes tendency of the analyzed index during the vegetation season were also defined. It was noticed that extreme droughts appeared four times less frequently than the normal months. Very dry months were noted most frequently in September while moderately dry - in August. The analysis of the frequency of spatial distribution of particular drought classes showed that extreme dry and very dry months occurred most frequently in western part of the area examined, while the moderately dry months also in south-eastern part. On the basis of the linear trend analysis it can be said that the SPI index values were slightly decreasing year by year.
\end{abstract}

Keywords: standardized precipitation index (SPI), time trend, central-eastern Poland.

\section{INTRODUCTION}

Drought is an atmospheric as well as soil and hydrological phenomenon. It is related to the period with no precipitation or to the repeated less than medium precipitation. To be able to fight negative consequences of drought effectively one should possess proven and reliable coefficients to define drought. One of them is SPI - standardized precipitation index [Bąk and Łabędzki 2004, Lana 2001, Lloyd-Hughes and Saunders 2002, Turke's and Tatlı 2009, Wu et al. 2005]. Coefficient's value shows precipitation's deviation from the average value in a multi-year. It is used to detect periods of drought and to assess its intensity on a variety of time scales. SPI index is used in many countries for operational monitoring of meteorological drought, e.g. in USA in National Drought Mitigation Center (NDMC) [ tabędzki 2006, McKee et al. 1993]. The analysis of fre- quency of occurrence, intensity and duration of drought during vegetation season is very important from the viewpoint of agriculture because it is an important factor that limits yielding of crops.

The aim of this paper was to determine, on the basis of SPI index, the frequency and intensity of drought occurrence during vegetation season in central-eastern Poland. Moreover, the attention was paid to the scope of variation of the examined coefficient during the time series analyzed. Statistical significance of directional coefficients of linear trends was also examined.

\section{MATERIALS AND METHODS}

The data used in this paper concerning daily sums of precipitation come from nine Institute of Meteorology and Water Management stations from central-eastern region of Poland from the years 1971-2005 (Table 1). 
The assessment of drought was made on the basis of standardized precipitation index (SPI).

$$
S P I=\frac{f(P)-\mu}{\sigma}
$$

where: $S P I$ - standardized precipitation index, $f(P)=\sqrt[3]{P}$-transformed precipitation sum,

$\mu \quad$ - average value of normalized precipitation series,

$\sigma \quad$ - average standard deviation of normalized precipitation series.

Table 1. Geographic coordinates of synoptic and climatic IMGW stations in central-eastern Poland

\begin{tabular}{|c|c|c|c|}
\hline \multirow{2}{*}{ Station } & \multicolumn{2}{|c|}{ Geographic coordinates } & \multirow{2}{*}{$\begin{array}{c}\mathrm{H}_{\mathrm{s}} \\
\mathrm{m} \text { a.s.l }\end{array}$} \\
\hline & $\varphi^{\circ}$ & $\lambda^{\circ}$ & \\
\hline Ostrołęka & $53^{\circ} 05^{\prime}$ & $21^{\circ} 34^{\prime}$ & 95 \\
\hline Białowieża & $52^{\circ} 42^{\prime}$ & $23^{\circ} 51^{\prime}$ & 164 \\
\hline Włodawa & $51^{\circ} 33^{\prime}$ & $23^{\circ} 32^{\prime}$ & 163 \\
\hline Szepietowo & $52^{\circ} 51^{\prime}$ & $22^{\circ} 33^{\prime}$ & 150 \\
\hline Legionowo & $52^{\circ} 24^{\prime}$ & $20^{\circ} 58^{\prime}$ & 93 \\
\hline Biała Podlaska & $52^{\circ} 02^{\prime}$ & $23^{\circ} 05^{\prime}$ & 133 \\
\hline Sobieszyn & $51^{\circ} 37^{\prime}$ & $22^{\circ} 09^{\prime}$ & 135 \\
\hline Pułtusk & $52^{\circ} 44^{\prime}$ & $21^{\circ} 06^{\prime}$ & 95 \\
\hline Siedlce & $52^{\circ} 11^{\prime}$ & $22^{\circ} 16^{\prime}$ & 146 \\
\hline
\end{tabular}

Explanations: $\varphi^{\circ}-$ geographic latitude, $\lambda^{\circ}-$ geographic longitude, $\mathrm{H}_{\mathrm{s}}$ - elevation above sea level.

In practice the following fact is commonly used: for random variable $X$ with gamma distribution variable $Z=\sqrt[3]{X}$ has approximately a normal distribution. Using that fact an approximate method of calculating SPI index can be suggested through standardization of random variable $Z=\sqrt[3]{X}$ [Gąsiorek et al. 2012].

Table 2 presents ranges of values (drought classes) for each of the vegetation season's months.

The frequency of occurrence of drought classes was examined in particular months of vegetation season in nine stations in central-eastern Poland and spatial distribution of the frequency of their oc-

Table 2. Drought classes according to standardized precipitation index SPI

\begin{tabular}{|c|l|}
\hline SPI index & \multicolumn{1}{|c|}{ Type of period } \\
\hline$\leq-2$ & extremely dry \\
\hline From -1 to -1.50 & very dry \\
\hline From -1.49 to -0.49 & moderately dry \\
\hline From -0.48 to 0.49 & normal \\
\hline
\end{tabular}

currence was presented as well. The frequency of drought occurrence in a specific month was calculated as the ratio of the number of cases of drought in a given month over the multi-year (1971-2005) to the number of 35 years being analyzed.

The basic characteristics of the distribution have been determined: the arithmetic mean, the minimum and the maximum. In order to express the dynamics of changes of the coefficient during the period examined, the standard deviations were calculated. The direction and significance of changes tendency were determined on the basis of the linear trend equations. The significance of directional coefficient of the trend was estimated with t-Student test where $\alpha=0.05$.

\section{RESULTS AND DISCUSSION}

During the multi-year analyzed in centraleastern Poland the lowest value of SPI index was noted in June in Białowieża (-5.94) and in August in Ostrołęka (-5.77), Białowieża (-5.71) and BiałaPodlaska (-5.00) (Table 3).

While the highest values occured in June in Legionowo (4.21) and in August also in Legionowo (4.63) and Siedlce (4.00).

Extremely dry months occurred most frequently in western part of the region examined (frequency about $10 \%$ ), while the least frequently in central and eastern part (frequency about $8 \%$ ) (Figure 1).

Very dry months were noted with the highest frequency in western and southern part of the region examined (frequency above 14\%) and moderately dry in western and south-eastern part (frequency above 30\%). Whereas optimally humid (normal) vegetation seasons occurred most frequently in southern part (frequency in Sobieszyn - 36\%).

In central-eastern Poland in all of the stations during vegetation season extremely dry and very dry months occurred most rarely, while normal and moderately dry months were most common. In the multi-year analyzed normal months occurred with the frequency from $30 \%$ (September) to $35 \%$ (May and July), moderately dry months from $26 \%$ (May) to $34 \%$ (September), very dry months from 9\% (May) to 14\% (September), extremely dry months from 6\% (August) to 9\% (April, May and July) (Table 4).

Łabędzki and Bąk [2004] defining SPI index variety in Poland in years 1954-1998 concluded that dry periods with different intensity 
Table 3. Average, minimum and maximum values of standardized precipitation index SPI during the vegetation season in central-eastern Poland between the years 1971-2005

\begin{tabular}{|c|c|c|c|c|c|c|c|}
\hline \multirow{2}{*}{\multicolumn{2}{|c|}{ Station }} & \multicolumn{6}{|c|}{ Month } \\
\hline & & \multirow{2}{*}{$\frac{\mathrm{IV}}{-3.38}$} & \multirow{2}{*}{$\frac{V}{-2.08}$} & \multirow{2}{*}{$\frac{\mathrm{VI}}{-3.46}$} & \multirow{2}{*}{$\frac{\text { VII }}{-2.96}$} & \multirow{2}{*}{$\frac{\text { VIII }}{-5.77}$} & \multirow{2}{*}{$\frac{\text { IX }}{-3.03}$} \\
\hline \multirow{3}{*}{ Ostrołęka } & $\min$ & & & & & & \\
\hline & $\max$ & 2.42 & 2.07 & 2.28 & 2.54 & 2.31 & 3.37 \\
\hline & average & -0.23 & -0.23 & -0.28 & -0.23 & -0.32 & -0.29 \\
\hline \multirow{3}{*}{ Białowieża } & $\min$ & -2.93 & -4.14 & -5.94 & -3.88 & -5.71 & -6.33 \\
\hline & $\max$ & 2.27 & 1.82 & 2.27 & 2.23 & 2.88 & 1.79 \\
\hline & average & -0.23 & -0.24 & -0.30 & -0.25 & -0.28 & -0.27 \\
\hline \multirow{3}{*}{ Włodawa } & $\min$ & -2.08 & -3.37 & -4.66 & -3.30 & -4.00 & -2.88 \\
\hline & $\max$ & 2.99 & 2.28 & 3.17 & 2.13 & 1.66 & 1.86 \\
\hline & average & -0.07 & -0.17 & -0.24 & -0.22 & -0.22 & -0.18 \\
\hline \multirow{3}{*}{ Szepietowo } & $\min$ & -2.42 & -4.42 & -3.11 & -3.43 & -2.70 & -2.57 \\
\hline & $\max$ & 1.61 & 2.92 & 3.00 & 2.81 & 2.59 & 2.14 \\
\hline & average & -0.21 & -0.20 & -0.23 & -0.26 & -0.14 & -0.26 \\
\hline \multirow{3}{*}{ Legionowo } & $\min$ & -2.90 & -2.83 & -3.89 & -2.93 & -3.10 & -2.51 \\
\hline & $\max$ & 2.46 & 1.82 & 4.21 & 2.70 & 4.63 & 2.66 \\
\hline & average & -0.25 & -0.09 & -0.13 & -0.18 & -0.29 & -0.29 \\
\hline \multirow{3}{*}{ BiałaPodl. } & $\min$ & -2.60 & -3.53 & -3.51 & -2.31 & -5.00 & -3.09 \\
\hline & $\max$ & 2.62 & 2.58 & 2.09 & 2.73 & 2.02 & 2.27 \\
\hline & average & -0.21 & -0.12 & -0.24 & -0.21 & -0.32 & -0.13 \\
\hline \multirow{3}{*}{ Sobieszyn } & $\min$ & -2.37 & -2.45 & -2.06 & -3.53 & -3.37 & -2.25 \\
\hline & $\max$ & 2.20 & 2.62 & 2.53 & 2.60 & 2.46 & 1.98 \\
\hline & average & 0.00 & -0.05 & -0.20 & -0.19 & -0.21 & -0.18 \\
\hline \multirow{3}{*}{ Pultusk } & $\min$ & -3.10 & -2.35 & -3.03 & -2.69 & -3.91 & -3.02 \\
\hline & $\max$ & 2.58 & 2.80 & 2.65 & 2.36 & 3.00 & 2.24 \\
\hline & average & -0.30 & -0.13 & -0.25 & -0.23 & -0.23 & -0.25 \\
\hline \multirow{3}{*}{ Siedlce } & $\min$ & -2.57 & -2.38 & -2.96 & -2.30 & -4.72 & -1.80 \\
\hline & $\max$ & 2.80 & 2.50 & 3.58 & 2.67 & 4.00 & 2.01 \\
\hline & average & -0.03 & 0.00 & 0.09 & -0.04 & 0.00 & -0.04 \\
\hline
\end{tabular}

Table 4. Average territorial frequency of occurrence (\%) of particular humidity classes (type of month) during the vegetation season (IV-IX) in central-eastern Poland between the years 1971-2005

\begin{tabular}{|l|c|c|c|c|c|c|c|}
\hline \multicolumn{1}{|c|}{ Droughtclass/month } & IV & V & VI & VII & VIII & IX & Average IV-IX \\
\hline Extremely dry & 9 & 9 & 8 & 9 & 6 & 7 & 8 \\
\hline Very dry & 12 & 9 & 13 & 12 & 13 & 14 & 12 \\
\hline Moderately dry & 27 & 26 & 30 & 29 & 34 & 31 & 29 \\
\hline Normal & 32 & 35 & 32 & 35 & 33 & 30 & 33 \\
\hline
\end{tabular}

of precipitation deficiency lasted for about $1 / 3$ part of the whole vegetation season. Among the driest months were mentioned May and July, while the least dry - August. Extreme droughts occurred most frequently in August, very dry periods in May and moderately dry in May and July. Łabędzki's studies [2008] during the years 1961-2006 from the station Bygdoszcz - IMUZ show that the frequency of the months in which drought was identified was $40-45 \%$ for various time scales. On the other hand Kanecka-Geszke and Smarzyńska [2007] claimed that according to SPI during the whole 35 years period (19702004) in the four out of five stations examined (Bydgoszcz, Kraków, Suwałki, Szczecin) there were $16(46 \%)$ vegetation periods with drought, and in one (Wrocław) - 17 vegetation periods with drought. 

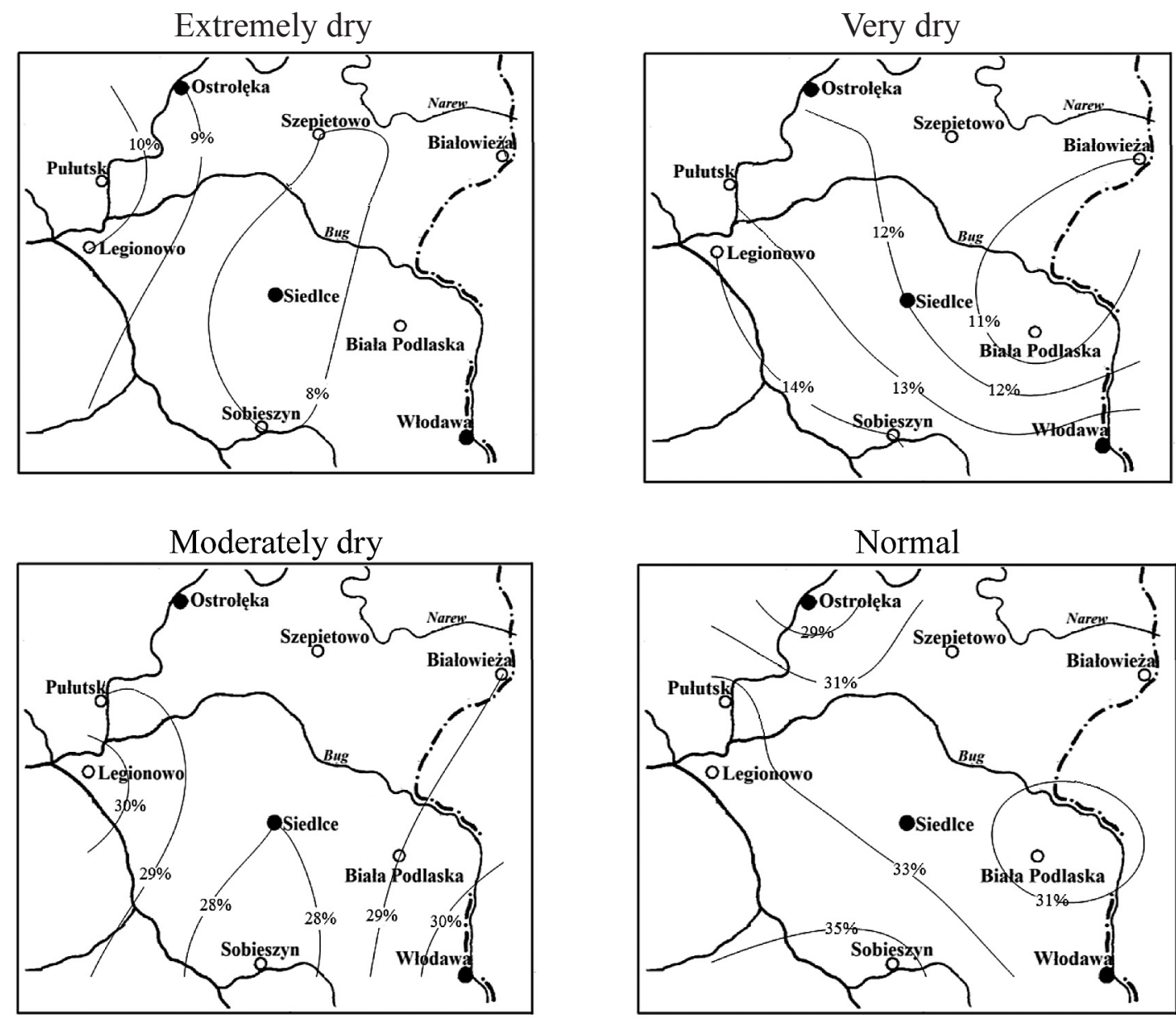

Figure 1. Frequency of occurrence (\%) of particular humidity classes during the vegetation season (IV-IX) in stations of central-eastern Poland between the years 1971-2005

Variability of average SPI index values during vegetation period (IV-IX) in all of the stations was on a similar level. Standard deviation value balanced from 0.34 in Włodawa to 0.48 in Legionowo (Table 5).

Table 5. Values of directional coefficients of the trend and of coefficients of variation of Sielianinow's coefficient during vegetation season (IV-IX) in centraleastern Poland between the years 1971-2005

\begin{tabular}{|l|c|c|}
\hline \multicolumn{1}{|c|}{ Station } & $\begin{array}{c}\text { Directional coefficient } \\
\text { of the trend }(\mathrm{a})\end{array}$ & $\begin{array}{c}\text { Standard } \\
\text { deviation }\end{array}$ \\
\hline Ostrołęka & -0.006 & 0.41 \\
\hline Białowieża & -0.013 & 0.46 \\
\hline Włodawa & -0.010 & 0.34 \\
\hline Szepietowo & $-0.014^{*}$ & 0.41 \\
\hline Legionowo & -0.014 & 0.48 \\
\hline Biała Podlaska & -0.008 & 0.40 \\
\hline Sobieszyn & -0.014 & 0.45 \\
\hline Pułtusk & -0.006 & 0.44 \\
\hline Siedlce & $-0.014^{*}$ & 0.39 \\
\hline
\end{tabular}

Explanations: * significant at $\alpha=0.05$.
On the basis of the analysis of directional coefficients of the trend values it can be stated that SPI index values were slightly decreasing year by year. Whereas statistically significant changes were noted only in Szepietowo and Siedlce. SPI index in those stations was decreasing about 0.14 within 10 years. Different tendencies of precipitation changes are observed in particular months in different regions of Poland [Banaszkiewicz et al. 2007, Musiał and Rojek 2007].

\section{CONCLUSIONS}

1. Variability of average SPI index values during vegetation season (1971-2005) in centraleastern Poland remained on a similar level.

2. During the vegetation season of the multi-year analyzed extreme droughts occurred four times less frequently than normal months, with at the same time similar frequency of occurrence in separate months. Whereas very dry months 
were noted most frequently in September and moderately dry - in August.

3. The analysis of frequency of spatial distribution of particular drought classes showed that extremely dry and very dry months occurred most frequently in western part of the area examined while moderately dry also in southeastern part.

4. On the basis of the linear trend analysis it can be stated that SPI index values were slightly decreasing year by year. Statistically significant changes were noted only in Szepietowo and Siedlce (about 0.14 within 10 years).

5. Standardized precipitation index SPI allows to evaluate the atmospheric drought. It can be used to monitor the atmospheric drought as well but in relation to the agricultural needs, further analysis of the soil and hydrological effects is a must. Its value depends in a large extent on precipitation variability.

\section{REFERENCES}

1. Banaszkiewicz B., Grabowska K., Suchecki S. 2007. Characteristics of Precipitation Conditions in Suwałki Lake district in the years 1971-2000. Scientific Review Engineering and Environmental Sciences 3 (37), 23-32.

2. Bąk B., Łabędzki L. 2002. Assessing drought severity with the relative precipitation index (RPI) and the standardized precipitation index (SPI). J. Water Land Develop. 6, 89-105.

3. Bąk B., Łabędzki L. 2004. Standardized climatic water balance as drought index. Acta Agrophisica 3(1), 275-283.

4. Kanecka-Geszke E., Smarzyńska K. 2007. Assessing meteorological drought in some agro-climatic regions of Poland by using different indices. Acta Sci. Pol., Formatio Circumiectus 6 (2), 41-50.
5. Gąsiorek E., Grządziel M., Musiał E., Rojek M., 2012. Determination of relative precipitation index based on standardized precipitation index for monthly precipitation sums. Infrastructure and Ecology of Rural Areas, 3/III, 197-208.

6. Lana X., Serra C., Burgueno A. 2001. Patterns of monthly rainfall shortage and excess in terms of the standardized precipitation index. International Journal of Climatology 21, 1669-1691.

7. Lloyd-Hughes B., Saunders M. 2002. A drought climatology for Europe.International Journal of Climatology, 22, 1571-1592.

8. Łabędzki L. 2006. Agricultural drought - an outline of the problems and methods of monitoring and classification. Water-Environment-Rular Areas, 17, pp. 107.

9. Łabędzki L. 2008. Estimation of different duration drought frequency using the StandardizedPrecipitation Index SPI. Zeszyty Problemowe Postępu Nauk Rolniczych, 526, 105-112.

10. Łabędzki L., Bąk B. 2004. Differentiation of the atmospheric drought index SPI in the vegetation period in Poland. Water-Environment-Rular Areas 4, 2a(11), 111-122.

11. McKee T.B., Doesken N.J., Kleist J. 1993. The relationship of drought frequency and duration to time scales. Proc. of the 8th Conference of Applied Climatology, 17-22 January 1993, Anaheim, California, 179-184.

12. Musiał E., Rojek M.S. 2007. Potential evapotranspiration and precipitation in Wrocław-Swojec during the period 1965-2000. Acta Agrophysica 9(3), 685-698.

13. Turke's, M., Tatl1 H. 2009. Use of the standardized precipitation index (SPI) and a modified SPI for shaping the drought probabilities over Turkey. International Journal of Climatology 29, 2270-2282.

14. Wu H., Hayes M.J., Wilhite D.A., Svoboda M.D. 2005. The effect of the length of record on the standardized precipitation index calculation. International Journal of Climatology 25, 505-520. 